\title{
HPLC assay of lidocaine in in vitro dissolution test of the Poloxamer 407 gels
}

\author{
Eduardo Ricci Júnior, Maria Vitória Lopes Badra Bentley, Juliana Maldonado Marchetti* \\ School of Pharmaceutical Sciences of Ribeirão Preto, University of São Paulo
}

*Correspondence:

J. Maldonado Marchetti

School of Pharmaceutical Sciences of

Ribeirão Preto

University of São Paulo

Av. do Café, s/n

14040-903 - Ribeirão Preto - São

Paulo, Brazil

E-mail: jmarchet@usp.br
A simple high performance liquid chromatography method to assay lidocaine hydrochloride in aqueous receiving media, following in vitro release, is presented. Lidocaine hydrochloride was analysed using a $5 \mathrm{~mm}$ LichroCART ${ }^{\circledR} R$-18 column (125 $x 4 \mathrm{~mm}$ i.d.). The mobile phase was acetonitrile: $0.05 \mathrm{M}$ sodium phosphate buffer, pH 6.0 (35:65) and 0.05\% of diethylamine at a flow rate of $1 \mathrm{~mL} / \mathrm{min}$. The retention time was $7.9 \mathrm{~min}$. Detection was carried out at $210 \mathrm{~nm}$ at room temperature $\left(28^{\circ} \mathrm{C}\right)$. The method was found to be linear in the range 1.25 to $25 \mathrm{mg} / \mathrm{mL}$, showing average intraassay and inter-assay coefficients of variation below 3.5\%. The proposed method was validated for linearity, specificity, precision and accuracy and was shown to be useful for the analysis of lidocaine hydrochloride in in vitro release studies.
Uniterms:

- Lidocaine hydrochloride

- HPLC

- Validation

- Release studies

- Thermoreversible gels

\section{INTRODUCTION}

Lidocaine hydrochloride, a widely employed local anesthetic drug, is also used following central spinal, epidural or peripheral administration, for topical management of major pain. Clinics favor local administration of anesthetics for the relief of local pain due to the convenience of this type of application as well as to its reduced adverse effects (Paavola et al., 1995,1998; Kang et al., 1999).

Poloxamer 407 is a polymer used in pharmaceutical preparations; absence of toxicity makes them suitable for drug delivery as well (Johnston, Miller, 1985). Poloxamer 407 gels may be used in delivery systems that require a sol-gel transition at body temperature. The solutions are highly viscous gels at room temperature but become liquids at refrigerator temperature (Schmolka, 1972). This permits injection of a fluid solution that at physiological temperatures forms a gel in situ.

Methods that extend the action of local anesthetics are important, because their short duration of action limits their use in the treatment of chronic pain. The evaluation of thermoreversible gels for sustained release of lidocaine hydrochloride is therefore of interest.

Studies on in vitro release of drugs from these types of gels have received considerable attention (Paavola et al., 1995, 1998; Barichello et al., 1999; Veyries et al., 1999; Shin et al., 2000). In these studies, drug release is measured using a dissolution apparatus under stirring, and a barrier membrane of synthetic origin. The receptor compartment contains, generally, isotonic phosphate buffer solution as receptor medium, maintained at $\mathrm{pH} 7.2$ and $37^{\circ} \mathrm{C}$ to mimic physiological conditions. Samples for analysis are removed from this compartment at regular intervals.

Since the amount of drug in acceptor aqueous fluid are usually small, sensitive and specific analytical methods to their determination are usually required. Among various assays techniques which may be employed, high performance liquid chromatography (HPLC) is prominent due to their potential specificity and sensitivity. 
High performance liquid chromatography (HPLC) has been used for the determination of lidocaine in serum, urine, plasma and pharmaceutical dosage forms (Chen et al., 1992; Lotfi et al., 1997; Kang et al., 1999). A precise and sensitive method for the determination of lidocaine in aqueous medium, by HPLC, from in vitro release studies has not been reported.

The aim of the present work is to set up a rapid and simple method for lidocaine assay in vitro release from Poloxamer 407 gel.

\section{MATERIALS AND METHODS}

\section{Reagents and materials}

Lidocaine was obtained from Sigma-Chemical (St. Louis, USA). Acetonitrile and methanol HPLC reagent grade were obtained from Merck (Darmstadt, Germany). Poloxamer 407 was obtained from BASF (USA). Diethylamine of HPLC reagent grade was obtained from Riedel-de-Haën (Seeize, Germany). Sodium dihydrogenphosphate and sodium monohydrogenphosphate of analytical grade were from Ecibra (São Paulo, Brazil) and Nuclear (São Paulo, Brazil), respectively. Water was obtained by following purification in a Milli-Q water (Millipore) system.

\section{Gel preparation}

Gels were prepared using the cold method (Schmolka, 1972). An appropriate amount of Poloxamer 407 to yield 20,25 and $30 \%$ gels was slowly added to cold destilled water $\left(5^{\circ} \mathrm{C}\right)$ maintaining constant stirring. The dispersion was kept in the refrigerator until a clear solution was formed (6-12 h). An appropriated amount of lidocaine hydrochloride to yield $2 \%$ was then dissolved in the cold solution. Poloxamer 407 gels with $2 \%$ lidocaine hydrochloride were autoclaved at $120^{\circ} \mathrm{C}$ for $30 \mathrm{~min}$ and stored in refrigerator.

\section{Standard solutions}

From a stock solution containing $1.0 \mathrm{mg}$ lidocaine hydrochloride $/ \mathrm{mL}$ in methanol, a standard curve was prepared at the concentration of $5,10,20,50$ and $100 \mu \mathrm{g} / \mathrm{mL}$ in methanol. For standardization, $25 \mathrm{~mL}$ of the standard solutions of lidocaine hydrochloride in methanol were transferred to glass tubes; methanol was evaporated under air stream at room temperature, and the residues dissolved in $100 \mu \mathrm{L}$ of mobile phase, by vortex mixing for $30 \mathrm{sec}$. The concentration range of standard curve was diluted four times in mobile phase and the corresponding solution was submitted to chromatographic analysis at 1.25 , 2.5, $5.0,12.5$ and $25.0 \mu \mathrm{g} / \mathrm{mL}$ of lidocaine hydrocloride.

\section{Chromatographic analyses}

The HPLC system employed was a Shimadzu liquid chromatograph, model SPD 10A VP using a variable wavelength UV detector set at $210 \mathrm{~nm}$, an LC-10 ADVP pump, a Rheodyne injector and a model CR6-A integrator. Separation was performed on $\mathrm{C}_{18}$ reversed-phase column LichroCART $^{\circledR}$ (Merck) 125 x $4 \mathrm{~mm}(5 \mathrm{~mm})$ and a $\mathrm{C}_{18}$ precolumn $4 \times 4 \mathrm{~mm}(5 \mathrm{~mm})$, at room temperature $\left(28^{\circ} \mathrm{C}\right)$. A (35:65) acetonitrile: $0.05 \mathrm{M}$ sodium phosphate buffer $\mathrm{pH}$ 6.0 mixture containing $0.05 \%$ diethylamine was used as mobile phase, at a flow rate of $1 \mathrm{~mL} / \mathrm{min}$ and injection volume of $20 \mu \mathrm{L}$

\section{Assay validation}

Lidocaine hydrochloride standard solutions containing 1.25 to $25 \mu \mathrm{g} / \mathrm{mL}$ were submitted to HPLC analysis in triplicate. Precision and linearity over this concentration range were assessed. Precision was calculated from the coefficient of variation $(\mathrm{CV} \%)$ of the standard curve and linearity was assessed from the linear regression.

Selective study was made with: isotonic phosphate buffer pH 7.2, 20\% Poloxamer 407 gel dissolved in isotonic phosphate buffer $\mathrm{pH} 7.2$, dried $25.0 \mu \mathrm{g} / \mathrm{mL}$ lidocaine hydrochloride solution in mobile phase and lidocaine hydrochloride in isotonic phosphate buffer $\mathrm{pH}$ 7.2 after released from the gel.

The limit of quantification was defined by the lowest amount of analyte that could be reproducibly quantified with a precision below $10 \%$. Precision was calculated from the coefficient of variation ( $\mathrm{CV} \%)$. For the determination of intra-assay precision of the limit of quantification a standard curve was made in triplicate, and six aliquots of lidocaine hydrochloride, at the concentration of $0.25 \mu \mathrm{g} / \mathrm{mL}$ were analyzed.

\section{In vitro release studies}

Dialysis bag prepared from cellulose tubing with diameter of $1.0 \mathrm{~cm}$ and extension of $3.5 \mathrm{~cm}$ were filled with $0.5 \mathrm{~g}$ of the gel with lidocaine hydrochloride $2 \% \mathrm{w} / \mathrm{w}$. The bag was individually immersed in the recipient containing $60 \mathrm{~mL}$ of the receptor media, in this case isotonic phosphate buffer $\mathrm{pH}$ 7.2. The temperature was kept at $37^{\circ} \mathrm{C}$ and the receptor media was constantly stirred 
to maintain the sink conditions. At appropriate time intervals samples were taken from the receptor media and assayed by HPLC to determine the amount of lidocaine released from the gel.

\section{RESULTS}

Figure 1 shows typical chromatograms of respectively: dry methanol and dissolved in $100 \mu \mathrm{L}$ of mobile phase, isotonic phosphate buffer $\mathrm{pH} \mathrm{7.2,} \mathrm{lidocaine}$ hydrochloride solution $25.0 \mu \mathrm{g} / \mathrm{mL}$ after dry and dissolved in mobile phase and lidocaine hydrochloride in isotonic phosphate buffer $\mathrm{pH} 7.2$ released from the gel. The retention time of lidocaine was 7.9 min and the peak was symmetric.

The peak heights of lidocaine correlated linearly with concentration over the 1.25 to $25 \mu \mathrm{g} / \mathrm{mL}$ range. The precision of the standard curve was below $2 \%$. The correlation coefficient for each standardization plot exceeded 0.9996 . The mean regression equation was $\mathrm{y}=1438.9 \mathrm{x}-51.801$, where $(\mathrm{y})$ is the peak height and $(\mathrm{x})$ is the concentration of lidocaine hydrochloride in $\mu \mathrm{g} / \mathrm{mL}$.

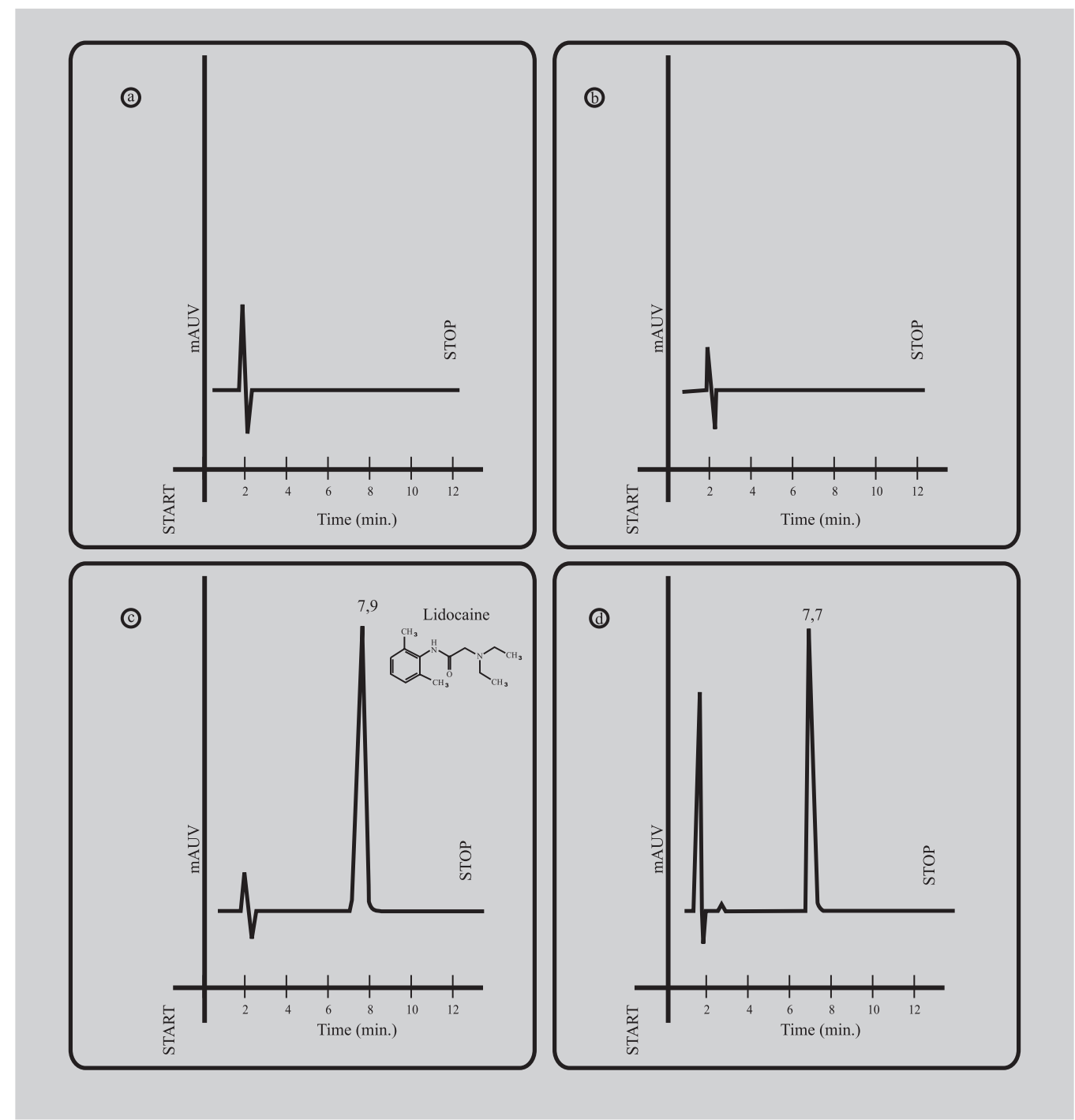

FIGURE 1 - Chromatograms of: (a) isotonic phosphate buffer pH 7.2; (b) 20\% Poloxamer 407 gel, dissolved in isotonic phosphate buffer $\mathrm{pH} 7.2$; (c) $25 \mu \mathrm{g} / \mathrm{mL}$ lidocaine hydrochloride solution in mobile phase and (d) lidocaine hydrochloride in isotonic phosphate buffer pH 7.2 after released from Poloxamer 407 gel. Retention time of lidocaine was $7.9 \mathrm{~min}$. Chromatographic conditions: 5 mm LichroCART ${ }^{\circledR}$ RP-18 (Merck) column (125 x 4 mm i.d.), 5 mm LichroCART ${ }^{\circledR}$ RP18 (Merck) pre-column (4 x 4 mm i.d.), acetonitrile:0.05 M sodium phosphate buffer pH 6.0 (35:65) as mobile phase, at a flow rate of $1 \mathrm{~mL} / \mathrm{min}$, detection at $210 \mathrm{~nm}$. 
The limit of quantification was $0.25 \mu \mathrm{g} / \mathrm{mL}$ with a precision below $5 \%$.

The intra-assay precision and accuracy of the assay (Table I) were determined by analysis of multiple spiked samples of lidocaine hydrochloride $(n=6)$. Aliquots of the same samples were analyzed on six consecutive days $(n=6)$ for evaluation of inter-assay precision and accuracy. The coefficients of variation for precision and accuracy were below $3.5 \%$.

TABLE I - Analysis of the precision and accuracy of the method for assay of lidocaine

\begin{tabular}{llc} 
Parameters & \multicolumn{2}{c}{ Lidocaine } \\
\hline Concentration $(\mu \mathrm{g} / \mathrm{mL})$ & 2.5 & 12.5 \\
$\mathrm{~N}^{\mathrm{a}}$ & 6 & 6 \\
Intra-assay precision $\left.(\mathrm{CV} \% \mathrm{~b})^{\mathrm{b}}\right)$ & 1.9 & 2.6 \\
\left.${\text { Inter-assay precision }\left(\mathrm{CV} \%^{\mathrm{b}}\right)}\right)$ & 3.5 & 1.1 \\
Intra-assay Accuracy $\left(\mathrm{E} \%^{\mathrm{c}}\right)$ & -2.1 & -2.2 \\
Inter-assay Accuracy $(\mathrm{E} \% \mathrm{c})$ & 0.1 & -2.0 \\
\hline
\end{tabular}

${ }^{a}$ corresponds to the number of determinations; ${ }^{b}$ coefficient of variation; ${ }^{\mathrm{c}}$ exactness

\section{DISCUSSION}

To run the HPLC analysis the composition of the mobile phase was, therefore, $35 \%$ acetonitrile, $65 \% 0.05$ $\mathrm{M}$ sodium phosphate buffer ( $\mathrm{pH} 6.0)$ and $0.05 \%$ diethylamine. The retention time of lidocaine was low, 7.9 min, and the peak was symmetric.

An important consideration regarding chromatographic methods is to decide whether to use an internal or external standard. For external standardization, the response of the analyte is plotted against concentration (Causon, 1999). External standard was chosen because hydrophilic lidocaine is very soluble in the receptor phase of in vitro release studies. Lidocaine does not have to be extracted from this receptor phase and can therefore be directly analyzed by HPLC.

The linearity range was 1.25 to $25.0 \mu \mathrm{g} / \mathrm{mL}$ with excellent correlation coefficient $(>0.9996)$ and the precision of standard curve was $2 \%$.

The limit of quantification was $0.25 \mu \mathrm{g} / \mathrm{mL}, 100$ times lower than the superior limit of the standard curve. The precision was $5 \%$.

The HPLC method for the determination of lidocaine hydrochloride showed excellent repeatability, reproducibility and accuracy (Table I). The precision and accuracy of the method were tested by within-day (intraassay) and between-day (inter-assay) analyses. To determine intra-assay precision and accuracy, the standard curve was made in triplicate and six aliquots of lidocaine hydrochloride solutions at concentrations of 2.5 and $12.5 \mu \mathrm{g} / \mathrm{mL}$, respectively, were analyzed as described above. The precision of analytical method is the measure of the random error, defined as the agreement between replicate measurements on the same samples. It can be considered as having a within-assay batch component or repeatability, which is also known as intra-assay precision. The ability to repeat the same methodology under different conditions or on subsequent occasions is known as inter-assay precision or reproducibility. The accuracy of an analytical method is a measure of the systematic error and is defined as the agreement between the measured value and the true value (Causon, 1999). Inter-assay precision and accuracy were calculated by analysis of aliquots of the same samples on six consecutive days.

Since no interfering peak from isotonic phosphate buffer components was observed (Figure 1), the proposed method proved to be selective for lidocaine assay in a usual receptor medium used for in vitro release studies. A selective analytical method should provide response function for a number of chemical entities that may or may not be distinguishable from each other. If the response function is distinguishable from all others, the method can be described as specific.

The in vitro release studies are qualitative control of the formulations and the analytic method is important to quantification of the lidocaine. There are many methods to quantification of the lidocaine in serum, urine, plasma and pharmaceutical dosage forms in the official literature or papers but such methods are complicated or of low sensitivity. The development of a simple, quick and sensitive method to quantification of the lidocaine in aqueous medium is very important.

This new method development to assay lidocaine has sensibility and selectivity to perform the proposed studies. The samples obtained from in vitro release studies have low concentration of lidocaine and they have been measured by HPLC. The method development is important to lidocaine quantification and detection of the interfering compounds of samples obtained from in vitro release studies.

The simplicity, sensitivity, selectivity and short running time of the proposed analytical method allow the analysis of large number of samples providing an useful, reliable means for the determination of lidocaine in aqueous medium. 


\section{ACKNOWLEDGEMENTS}

This research was supported by Fundação de Amparo à Pesquisa do Estado de São Paulo (FAPESP), Brazil. Dr. A. M. Rothschild provided redaction assistance.

\section{RESUMO}

\section{Ensaio de lidocaína por CLAE em teste de dissolução in vitro dos géis de Poloxamer 407}

Apresenta-se método simples de cromatografia líquida de alta eficiência (CLAE) para análise da lidocaína em meio aquoso, após estudo de liberação in vitro. A lidocaína foi analisada usando-se coluna LichroCART RP-18 $(5 \mathrm{~mm}$, $125 \times 4 \mathrm{~mm})$, fase móvel constituida de acetonitrila: tampão fosfato de sódio 0,05 M, pH 6 (35:65), adicionada de $0,05 \%$ de dietilamina com fluxo de $1 \mathrm{~mL} / \mathrm{min}$. O tempo de retenção foi de 7,9 min. O comprimento de onda de análise utilizado foi de $210 \mathrm{~nm}$. A linearidade do método foi de 1,25 a $25 \mu \mathrm{g} / \mathrm{mL}$ com coeficiente de variação intraensaio e inter-ensaio menor que 3,5\%. A metodologia desenvolvida e validada mostrou sensibilidade e especificidade para a realização dos estudos propostos, considerando-se que as amostras obtidas a partir dos estudos de liberação in vitro contêm concentrações muito baixas do fármaco, além de outras substâncias do meio de dissolução que podem interferir no doseamento. A quantificação do fármaco e dos interferentes pode não ser possivel se for efetuada por outras metodologias analiticas convencionais. Assim, o método desenvolvido é de grande importância para a quantificação do fármaco nas alíquotas obtidas nos ensaios de liberação in vitro.

UNITERMOS: Cloridrato de lidocaína. CLAE. Meio Aquoso. Estudos de liberação. Gel termo-reversivel.

\section{REFERENCES}

BARICHELLO, J. M., MORISHITA, M., TAKAYAMA, K., CHIBA, Y., TOKIWA, S., NAGAI, T. Enhanced rectal absorption of insulin-loaded Pluronic F-127 gels containing unsaturated fatty acids. Int. J. Pharm., Amsterdam, v. 183, p. 125-132, 1999.

CAUSON, R. Validation of chromatographic methods in biomedical analysis; viewpoint and discussion. $J$. Chromatogr. Biomed. Appl., Amsterdam, v. 689, p. 175180, 1999.
CHEN, Y., POTTER, J. M., RAVENSCROFT, P. J. High performance liquid chromatographic method for the simultaneous determination of monoethylglycinexylidide and lignocaine. $J$. Chromatogr. Biomed. Appl., Amsterdam, v. 574, p. 361364, 1992.

JOHNSTON, T. P., MILLER, S. C. Toxicological evaluation of poloxamer vehicle for intramuscular use. J. Parent. Sci. Technol., New York, v. 39, p. 83-89, 1985.

KANG, L., JUN, H. W., MACALL, J. W. HPLC assay of lidocaine in plasma with solid phase extration and UV detection. J. Pharm. Biomed. Anal., Amsterdam, v. 19, p. 737-745, 1999.

LOTFI, H., DEBORD, J., DREYFUSS, M. F., MARQUET, P., RHAIEM, M. B., FEISS, P., LACHÂTRE, G. Simultaneous determination of lidocaine and bupivacaine in human plasma: application to pharmacokinetics. Ther. Drug Monit., Philadelphia, v. 19, n. 2, p. 160-164, 1997.

PAAVOLA, A., YLIRUUSI, J., KAJIMOTO, Y., KALSO, K., WAHLSTRÖM, T., ROSEMBLY, P. Controlled release of lidocaine from injectables gels and efficacy in rat sciatic nerve block. Pharm. Res., New York, v. 12, p. 1997-2002, 1995.

PAAVOLA, A., TARKKILA, P., XU, M., WAHLSTRÖM, T., YLIRUUSI, J., ROSEMBLY, J. Controlled release gel of ibuprofen and lidocaine in epidural use - analgesia and systemic absorption in pig. Pharm. Res., New York, v. 15, p. 482-487, 1998.

SCHMOLKA, I. R. Artificial skin. I. Preparation and properties of Pluronic F-127 gels for treatment of burns. J. Biomed. Mater. Res., New York, v. 6, p. 571-582, 1972.

SHIN, S., CHO, C., OH, I. Enhanced efficacy by percutaneous absorption of piroxicam from the poloxamer gel in rats. Int. J. Pharm., Amsterdam, v. 193, p. 213-218, 2000.

VEYRIES, M. L., COUARRAZE, G., GEIGER, S., AGNELY, F., MASSIAS, L., KUNZLI, B., FAURISSON, F., ROUVEIX, B. Controlled release of vancomycin from Poloxamer 407 gels. Int. J. Pharm., Amsterdam , v. 192, p. 183-193, 1999.

Recebido para publicação em 01 de junho de 2001. 